Severe Chronic Obstructive Pulmonary Disease during Physical Therapy. Sport Mont. 2021. 19(S2). P.153-157. doi: 10.26773/smj.210926

3. Sitovskyi A. M., Radchenko O. V., Dmytruk V. S., Andriichuk O. Y., Roda O. B., Savchuk I. V. Heart Rate Variability in $12-$ to 13-Year-Old Adolescents. Neurophysiology. 2020. 52(4). P. 279-288 DOI:10.1007/s11062021-09883-8

4. Slyusar A.O., Sitovsky A. M. The level of motor activity of patients after ischemic stroke in the residual period of the disease. Proceedings of the XIV International scientific-practical conference of graduate students and students "Young Science of Volyn: priorities and prospects for research". Lutsk: University. Lesia Ukrainka, 2021. P. 384-386.

DOI https://doi.org/10.30525/978-9934-26-182-4-51

\title{
ВИВЧЕННЯ ОСОБЛИВОСТІ МІГРАЦІЇ СПІРОМЕЗІФЕНУ В ГРУНТОВІ ВОДИ ТА ПОВЕРХНЕВІ ВОДИ І ПРОГНОЗУВАННЯ РИЗИКІВ ДЛЯ ЗДОРОВ'Я ЛЮДИНИ ПРИ ВЖИВАННІ ТАКОЇ ВОДИ ДЛЯ ПИТНИХ ПОТРЕБ
}

Ткаченко I. B.

аспірант кафедри гігієни та екології № 1

Національний медичний університет імені О. О. Богомольия

Антоненко А. М.

доктор медичних наук, професор кафедри гігієни та екології № 1

Національний медичний університет імені О. О. Богомольия

Коршун М. М.

доктор медичних наук, професор кафедри гігієни та екології № 3 Національний медичний університет імені О. О. Богомольия м. Київ, Україна

За оцінками ВОO3, через ненавмисне отруєння від впливу пестицидів щорічно у світі гинуть орієнтовно 355 тис. осіб [1]. Основними шляхами 
потрапляння пестицидів до організму людини є вдихання пестицидної пари або пилу, потрапляння на шкіру, випадкове проковтування або надходження 3 продуктами харчування і водою, а головним джерелом розповсюдження препаратів $є$ агроценози [2, 3]. Міграція пестицидів по грунтовому профілю відбувається завдяки капілярно-гравітаційному переміщенню води. Швидкість і глибина їх проникнення залежать від безлічі факторів, пов'язаних як з грунтово-кліматичними особливостями (гранулометричним складом, вмістом колоїдів і сорбційною здатністю грунтів, кількістю опадів), так і 3 властивостями та дозами самих препаратів [1, 3, 4]. Більшість сільського населення (70 \%) України споживає воду з колодязя, тобто грунтову, так як проживає в умовах децентралізованого водопостачання. На відміну від міжпластових, артезіанських вод ця вода з більшою ймовірністю потенційно може бути забрудненою пестицидами [4].

Метою було вивчення особливості міграції спіромезіфену в грунтові води та поверхневі води і прогнозування ризиків для здоров'я людини при вживанні такої води для питних потре

Матеріали та методи. Натурні дослідження 3 вивчення динаміки залишкових кількостей спіромезіфену спіромезіфену у грунті проводили в різних грунтово-кліматичних умовах України: Степ, Лісостеп, Полісся (Одеська, Чернівецька, Київська області). Спосіб обробки - вентиляторне обприскування, культури - яблуневі сади та виноградник, норма витрати 0,8 л/га, двократно.

Стійкість спіромезіфену у грунті оцінювали за ДСанПін 8.8.1.002-98 [5],та Міжнародною класифікацією IUPAC [6], міграційну здатність за Міжнародною класифікацією SSLRC [7].

Для оцінки міграції у воду користувалися показниками GUS (Groundwater Ubiquity Score) - індекс потенційного вимивання, який показує ймовірність міграції речовини 3 грунту в підземні води [8] та $\mathrm{LEACH}_{\text {mod }}$ (Leaching Estimation and Chemistry) - індекс вилуговування для оцінки потенційного забруднення грунтових та річкових вод [9].

Для прогнозування ризику для людини при вживанні контамінованої води ми використали інтегральний вектор небезпечності забруднення грунтових вод (R) згідно [10] та інтегральний показник небезпечності при потраплянні пестицидів у воду (IПНВ) запропонований у [11].

Результати дослідження та їх обговорення. Період напівруйнування за даними літератури [12] спіромезіфену коливається від максимального значення 21 доба до мінімального 1,9 діб в залежності від грунтовокліматичних умов, складу грунту тощо. В усіх випадках за стійкістю у грунті відповідно до [5] та [6] досліджувана сполука належить до 3-4 класу 
небезпечності - помірно та мало стійкий. В грунтово-кліматичних умовах України $\tau_{50}$ досліджуваної сполуки становив менше 14 діб, що дозволяє віднести його за стійкістю у грунті до 4 і 3 клас небезпечності за [5] і [6], відповідно.

Основним чинником, який визначає швидкість руйнування та інстенсивність міграції пестицидів є сорбційно-десорбційна рівновага в системі пестицид-грунт. Спіромезіфен за значенням константи сорбції Кос належить до не мобільних речовин (5 клас) відповідно до [7]. Проте, потенційна небезпека підвищується при тривалій персистентності речовини у грунті, іiі високій розчинності у воді та значній гідролітичній стабільності, тому прогноз забруднення грунтових лише за К ос не може бути остаточним. Для більш детального вивчення цієї системи розрахували індекси GUS та LEACH.

Значення показника GUS за даними літератури [12] дорівнює -0,16, що свідчить про дуже низький або надзвичайно низький ризик потенційного вимивання спіромезіфену у грунтові води. За нашими власними дослідженнями розрахований індекс GUS становив -0,38. Отриманий результат свідчить про дуже низький або надзвичайно низький ризик надходження досліджуваного інсектициду в грунт при застосуванні препаратів на його основі. Обидва значення GUS дозволяють віднести сполуку до 6 класу небезпечності та за шкалою наведеною в [10] і $з$ оцінкою в 30 балів - до низького рівня небезпечності вимивання пестицидів у грунтові води.

Індекс вилуговування ( $\left.\mathrm{LEACH}_{\mathrm{mod}}\right)$ було розраховано за формулою [9]:

$$
\mathrm{LEACH}_{\text {mod }}=\frac{0,13 \times 6}{30900}=2,5 \times 10^{-5} \text {. }
$$

Ризик потенційного забруднення оцінюється як низький (3 клас небезпечності) відповідно до класифікації наведеної в [9].

Розраховані показники не дають нам можливість спрогнозувати потенційну небезпечність спіромезіфену для організму людини при можливому надходженні з контамінованою водою. Тому, наступним етапом нашого дослідження був розрахунок такого ризику.

Нами було розраховано інтегральний вектор небезпечності забруднення грунтових та поверхневих вод (R) згідно методики С.Г. Сергєєва зі співав. [10]:

$$
\begin{aligned}
& \mathrm{R}=\sqrt{30^{2}+50^{2}+50^{2}}=76,8 \text { (грунтові води); } \\
& \mathrm{R}=\sqrt{30^{2}+30^{2}+50^{2}}=65,6 \text { (підземні води). }
\end{aligned}
$$

За отриманими результатами розрахунку ризик забруднення грунтових та підземних вод спіромезіфеном в грунтово-кліматичних умовах України за інтегральним вектором $\mathrm{R}$ - середній згідно з [10]. 
Також було визначено інтегральний показник небезпечності при потраплянні пестицидів у воду за методикою запропонованою в [11]: $\mathrm{I \Pi HB}=1+2+2=5$ балів. Для розрахунку використали бальну оцінку індексу вимивання $\mathrm{LEACH}_{\mathrm{mod}}, \tau_{50}$ у воді (для грунтових вод - внаслідок гідролізу при $\mathrm{pH}=7$, для поверхневих вод - у водній фазі системи «водаосад») та ДДД відповідно.

За даною методикою [11] спіромезіфен визнається, як помірно небезпечна речовина для людини при міграції в системі «грунт-вода» (3клас) за забрудненням підземних вод та малонебезпечна (4 клас) для здоров'я населення при потенційному надходженні в поверхневі води.

Висновки. Встановлено, що спіромезіфен володіє низькою можливістю вимивання у грунтові води та низьким ризиком забруднення підземних і поверхневих вод. Сполука помірно небезпечна при споживанні людиною контамінованих підземних вод.

\section{Література:}

1. До уваги аграріїв: використання пестицидів без шкоди для здоров'я та навколишнього середовища. 2021. URL: https://tavrychanskagromada.gov.ua/news/1616069677/ (дата звернення 22.11.2021).

2. Озвучено особливості накопичення пестицидів у грунтах. 2021. URL: https://superagronom.com/news/13093-ozvucheno-osoblivosti-nakopichennya-pestitsidiv-v-gruntah (дата звернення 22.11.2021).

3. Хижняк С.В., Войціцький В.М., Данчук В.В. та ін. Шляхи міграції стійких пестицидів трофічними ланцюгами наземних i водних екосистем. Біоресурси і природокористування. 2018. Т. 10 (1-2). С. 36-43. DOI: 10.31548/bio2018.01.005.

4. Мартіянова Ю., Коршун М. Прогнозування ступеню небезпечності забруднення грунту, підземних та поверхневих вододжерел пестицидами 3 класів тріазолонів, трикетонів ка карбоксамідів залежно від грунтовокліматичних умов. Ukrainian Scientific Medical Youth Journal. 124 (2). 2021. C. 77-88. DOI: https://doi.org/10.32345/USMYJ.2(124).2021.77-88.

5. Пестициди. Класифікація за ступенем небезпечності: ДСанПіН 8.8.1.002-98 / Зб. важливих офіційних матеріалів 3 санітарних i протиепідемічних питань. Київ, 2000. Т. 9 (1). С. 249-266.

6. NPIC: National Pesticide Information Center. OSU Extension PesticideProperties Database. URL: http://npic.orst.edu/ingred/ppdmove.htm (дата звернення 23.11.2021).

7. Agricultural Substances Databases Agriculture \& Environment Research Unit. University of Hertfordshire. URL: http://sitem.herts.ac.uk/ aeru/iupac/docs/Background_and_Support.pdf (дата звернення 23.11.2021). 
8. Gustafson D.I. Groundwater ubiquity score: a simple method for assessing pesticide leachability. Environmental Toxicology and Chemistry. 1989. № 8. P. 339-357.

9. Claudia A. Spadotto. Screening method for assessing pesticide leaching potential. Pesticidas: R. Ecotoxicol. Curitiba. 2002. V. 12. P. 69-78.

10. Индикаторные критерии и прогноз опасности загрязнения подземных вод гербицидами на основе эфиров кислот. Современные проблемы токсикологи: за ред. Сергеев С.Г. и др. 2010. № 2-3. С. 76-79.

11. Antonenko A.M., Vavrinevych O.P., Omelchuk S.T., Korshun M.M. Prediction of pesticide risks to human health by drinking water extracted from underground sources. Georgian Medical News. 2015. № 7-8 (244-245). P. 99-106.

12. PPDB: Pesticide Properties DataBase. Spiromesifen. URL: http://sitem.herts.ac.uk/aeru/ppdb/en/Reports/598.htm (дата звернення 23.11.2021). 